\title{
Modification Trends of Terraced Houses: A case study of Section 7, Shah Alam, Selangor
}

\author{
Salehaton H. Sazally, Erdayu Os'hara Omar, \\ Hazlina Hamdan, Anniz Fazli Ibrahim Bajunid \\ Faculty of Architrcture, Planning and Surveying, \\ Universiti Teknologi MARA, Shah Alum, MALA YSIA. \\ salehaton@salam. uitm.edu.my
}

\begin{abstract}
Terraced or link houses have been one of the most popular housing schemes lived by modern Malaysians from all walks of life due to its design and affordability amongst all landed properties. Conversely, the mass housing production concept has its disadvantages and in most cases could not complement to the diverse individual needs and personal satisfaction of personalisation. The most distinctive evidence is the adhered normal practice to renovate or modify houses even as early as when the owner is given vacant possession of the property. Users make changes for various reasons such as for personal needs, functional requirements or just plainly for aesthetic appeal. Housing modification or occurs when users modify the interior or exterior physical components of their homes. Modification works ranges from a simple change of colour of the facade to major structural changes to the home. It is also much based on individual affordability and the timing J\{Jr the modifications to be made. A questionnaire survey was conducted in a terraced housing development in Section 7, Shah Alam, Selangor, to establish the personalisation trends and the motivational desires behind the personalisation.
\end{abstract}

Keywords: Housing, personalisation

eISSN 2514-751X @ 2016 The Authors. Published for AMER ABRA by e-International Publishing House, Ltd., UK.. This is an open access article under the CC BY-NC-ND license (http://creativecommons.org/licenses/by-ncnd/4.0/). Peer-review under responsibility of AMER (Association of Malaysian Environment-Behaviour Researchers), ABRA (Association of Behavioural Researchers on Asians) and cE-Bs (Centre for EnvironmentBehaviour Studies), Faculty of Architecture, Planning \& Surveying, UniversitiTeknologi MARA, Malaysia.

https://doi.org/10.21834/aje-bs.v1i1.166 


\subsection{Introduction}

A house can only be considered a 'home' to the extent that the occupiers can give it their own meaning... It may even be said that 'homes' develop 'in spite of' rather than 'because of' the house design. (Marcus, 1986, on Ruddick)

Why does renovation of homes occur extensively to the Malaysian terrace developments? And in some cases even prior to moving in a newly completed home? Presumably, it is for the enhancement of personalisation, in keeping with the unique needs of individual families. The perceived beauty of architectural features and personalisation however, through an architect's appraisal, would undeniably be different to that of a layperson. Ancient truth obvious since the times of Pythagoras, its conceptual golden section and precise geometrical specification dictates architectural beauty. While these terrace developments are constructed with these aesthetic appeals in mind, to the layperson, its attractiveness is not entirely dependent on the architect's practical experience and training. The owner's emotional response plays a distinct personal and contextual role (Gifford, et al, 2000). Personalisation of homes in terraced developments in this paper means modification of or addition to the dwelling exteriors, for example the front, back or side yards or of the facades. These changes of the immediate environment to the extent that it gives its own personalised meaning are in line with Rapoport's observations (Marcus \& Sarkissian, 1986). It is thus apparent that personalisation seems to occur despite countless design treatments and differentiation between residential neighbourhoods. This paper aims at understanding these trends to this personalisation process.

It is also universally known that humans often mark and personalise spaces they occupy be it fences and hedges or other symbols to identify the space to the owner (Hansen \& Altman, 1976). There are many ways of measuring the physical features of changes to a building. From Gifford, Hine, Muller-Clernrn, Reynolds JR., \& Shaw (2000), the use of The Architectural Coding System (TACS) using the Lens Model Approach is a detailed comprehensive measurement of the observer's impressions of a building. A simpler model of changes to architectural facades used by Stamps (1999) is determined by three factors of silhouettes, massing and surfacing. However, the model that best fits the context and perceptions of the owners in this particular limited field study is that of Marcus \& Sarkissian (1986). Territorial expression, added privacy, articulated facade, personal additions, components replacements, and entry personalisation are among the elements studied and surveyed within the target user groups.

Thus, the two main objectives of this paper are concentrated on descriptive behavioural analysis of modifications of residents in Section 7, Shah Alam, towards personalisation of their dwellings and establishing the personalisation trends and the motivations behind the undertaken personalisation. This descriptive analysis attempts to explain the situations in the personalisation to provide a better understanding of household behaviours which then become the catalyst for further detailed studies.

It must also be noted however, that due to limited resources of the study, the ethnic 
majority of the selected area (the Malays) has been identified and will undoubtedly restrict the findings, applicable to only that race and of the Islamic culture, values and lifestyle.

Nevertheless, the research objectives and methodology, in another research grant can also be taken to other areas of different races, cultures and lifestyles and be comparatively analysed for a holistic understanding of the Malaysian context.

\subsection{Methodology}

The study was based on questionnaire surveys conducted on residents living in Section 7, Shah Alam. Section 7 consists of various types of houses with low cost flats, medium -cost apartments, semi-detached houses, bungalows and the predominant terraced houses. There are 2184 units of terrace houses in Section 7 (MBSA, 2(04). The major housing typology of the terrace was chosen in this particular survey. The approach used in this survey was a household drop off survey, where 220 questionnaires were distributed systematically to three main areas in Section 7 (Figure I). The three main sections were identified by its distinct physical road boundaries. The selection of samples was based on a systematic sampling on houses that had been to some extent made some form of personalisation to its exterior. During the field survey, respondents were approached personally and given the questionnaires. In some cases, allocation of time to answer was given to the respondents and the questionnaire was picked up at a later time, as agreed by the respondents. A total of 204 questionnaires were returned and used for the data analysis

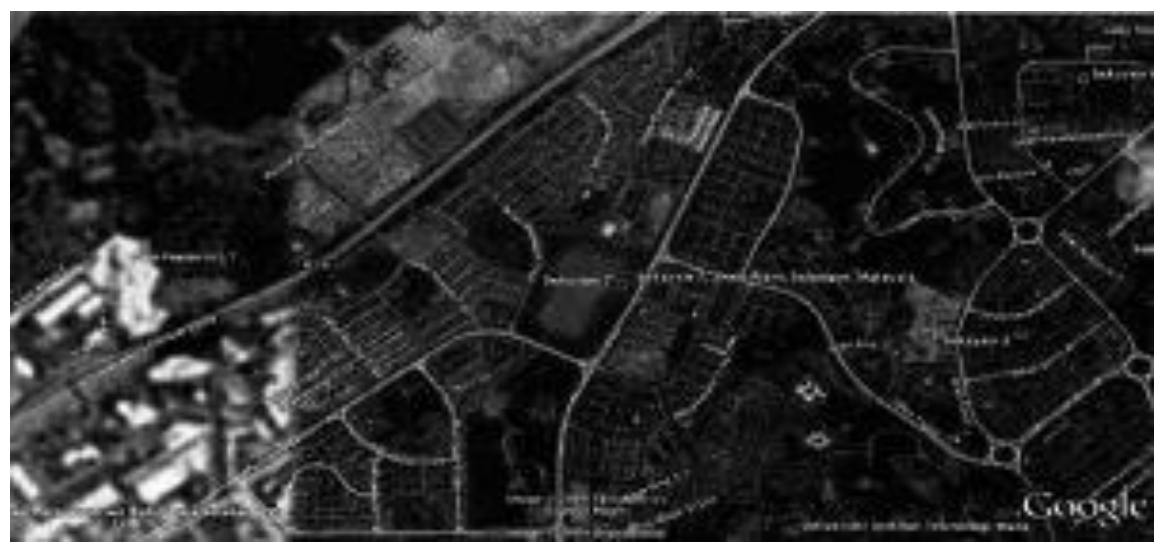

Figure 1: Section 7, Shah Alam

(Source: Google Earth (2009). Retrieved on 9th October 2009 from http://maps.google. com.my/maps?client=firefox-a\&rls=org.mozilla:en US:official\&hl=en\&tab=wl) 


\subsection{Results and Discussions}

\subsection{Areas of Personalisation}

For terrace houses, the most common type of exterior personalisation is the front, back and the side portion of the house. These three simple categories of exterior personalisation were used to better understand the needs and requirements of the respondents. There were 342 cases of renovation works done by the respondents in the study area. In Figure 2, personalisation of the front portion had the highest percentage with $47 \%$ casesofmodifications. Meanwhile $41 \%$ of respondents personalised the back portion of their houses and only $12 \%$ of corner unit respondents personalised the side portion of their houses.

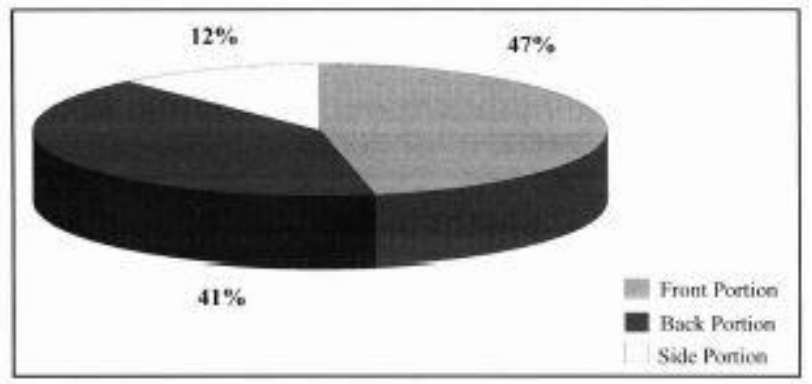

Figure 2: Areas of personalisation Modifications periods

Figure 3 shows when the modifications took place. The personalisation of the front portion, $48.4 \%$ of the respondents surveyed made renovations after having moved in for quite some time. However, when it comes to modifications to the back portion of the house, more than half of the respondents (55.3\%) made renovations before moving in. The same results appear for modifications on the side portion of the house with $62.5 \%$ of the respondents. This clearly shows that before moving in, respondents were more likely to personalise their houses by renovating the back and side portion of the house. Meanwhile modifications to the front portion were more likely to happen after moving in, only when the household felt the need to do so.

\subsection{Modifications costs}

Modification costs varied from the lowest renovation works of RM1000 to the highest cost of RM200,000. It represented the respondent's personalisaiion towards their dwellings at different levels of intensity, from the simplest adjustments to the renovations of entire facades. As shown in Figure4, the cost of modification is detailed out accordingly to the three areas of renovation. For the front portion, half of those who renovated this portion spent between RM 10,000 and RM29,999, followed by $19 \%$ for the cost of RM30,000 to RM49,999. The same pattern was also evident for the modification at the back portion of 
Sazally, S.H., et.al., / Asian Journal of Environment-Behaviour Studies, ajE-Bs, 1(1), Maiden, December 2016 (p.37-48)

the house. Costs between RM10,000 and RM29,999 were spent by $46 \%$ of those who renovated the back portion. Meanwhile, as shown in the Figure 4, the renovation costs for the side portion of the house was more or less evenly distributed.

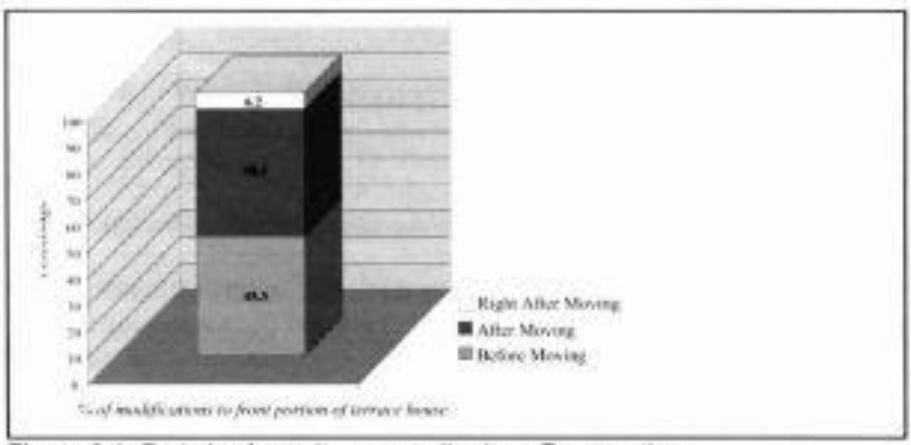

Figure 3.1: Periods of exterior personalsation - Front portion

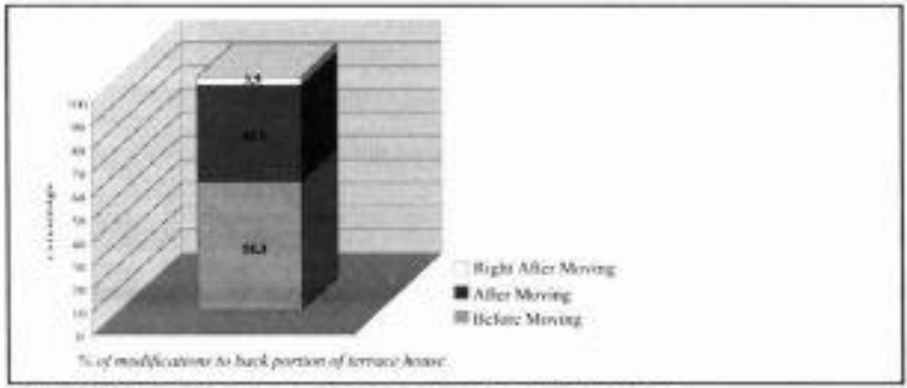

Figure 3.2: Periods of exterior personalisation - Back portion

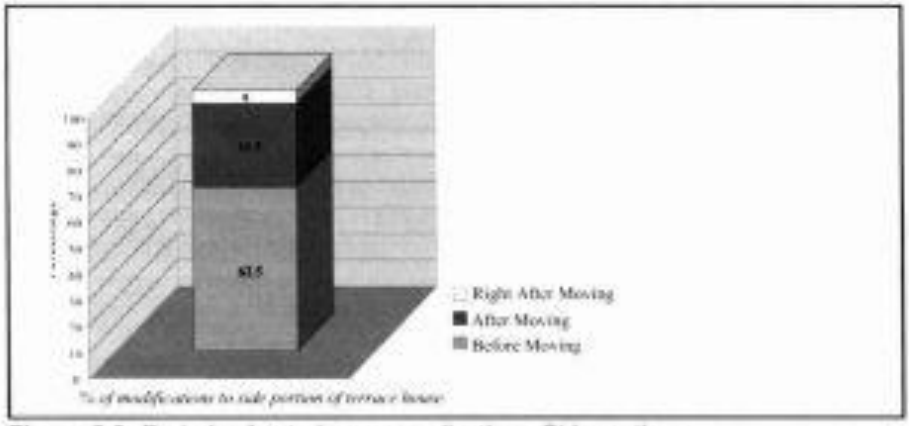

Figure 3.3: Periods ol exterior personalisation - Side pontion 


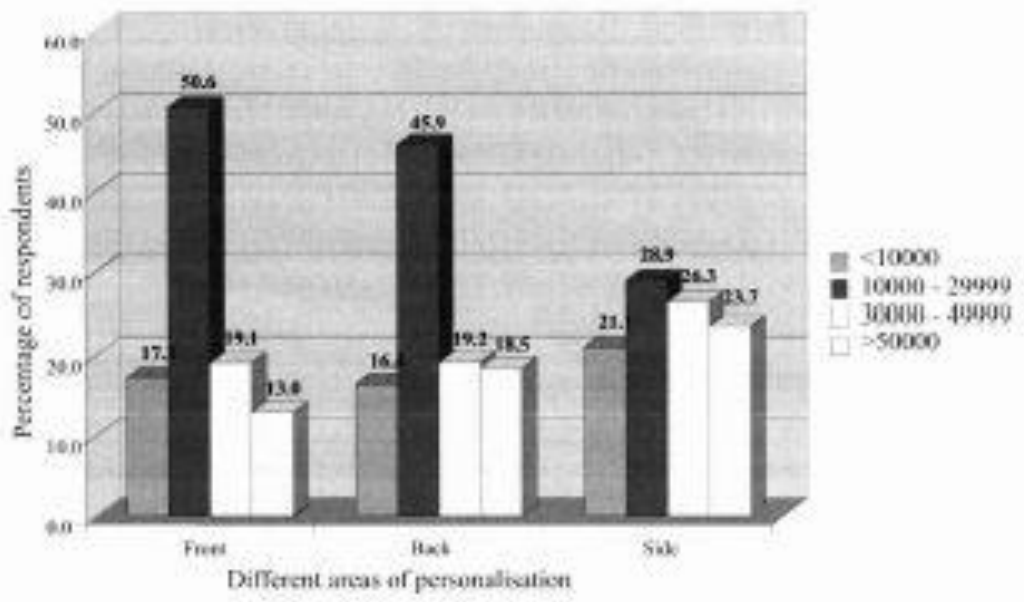

Figure 4: Cost of Modification

\subsection{Elements of modification}

Modification requires spending money, especially on elements that is important in the perceived personalisation of one's house. Based on the survey, the elements for modification were listed according to the three areas of the house and the respondent's response to what elements that had been done to make their houses more personalised. Using multiple response-dichotomy analysis, for the front portion of the modification, the top five ranking on the elements of modification were painting, grill, gate, porch, pavement and door. Each element and its percentage is presented in Table I.

For the back portion of the houses, the top five elements of modifications were painting, additional kitchen, grill, flooring and door. Painting was still the most common element to change in the personalisation of appearance of one's house. Additional kitchen space was needed as the current design of kitchen space in many terrace houses was rather small. With the allocation of the backyard and setback requirements, the additional space for wet kitchen was added for a bigger kitchen space. The addition of grilles at the back of the terrace house was ranked at number three for logical safety reasons. At rank number four was renovations to the flooring of the back area. Respondents making changes to the door most likely needed a better quality door material. The side portion of the house shows more or less the same pattern where painting ranked first. This was followed by the grille, window and wall respectively. Additional space also received a high ranking when more land was available to the side of the terrace house. These limited units renovated the side portion for aesthetics and for the perceived difference in appearance. 
Table 1: Elements of Modification

\begin{tabular}{|c|c|c|c|c|c|c|c|c|c|c|c|}
\hline $\begin{array}{l}\text { Frove } \\
\text { parson of } \\
\text { hestrowse }\end{array}$ & Coses & $\phi$ & Aarking & $\begin{array}{l}\text { Hask jorten } \\
\text { th me hoves }\end{array}$ & Cuvos & $\underline{-}$ & Rurting & $\begin{array}{l}\text { Sidn } \\
\text { peintorid } \\
\text { the nowe }\end{array}$ & Covons & $\mathbf{s}$ & Rarking \\
\hline Wridose & 100 & 52.2 & 7 & $\begin{array}{l}\text { Adebond } \\
\text { serom }\end{array}$ & 590 & 28 & 2 & Wroon & 29 & 537 & 3 \\
\hline Door & 197 & 81.3 & 5 & 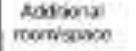 & $\theta \theta$ & 4:0 & $\mathbf{y}$ & Bocer & 21 & 89.9 & 7 \\
\hline $\begin{array}{l}\text { Enovesh } \\
\text { of sos } \\
\text { poreh }\end{array}$ & 90 & 486 & B & $\begin{array}{l}\text { Mddisansi } \\
\text { awning }\end{array}$ & 73 & di2 & 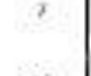 & Wal & 28 & 69.7 & 3 \\
\hline Gate & 142 & 75.1 & 3 & $\begin{array}{l}\text { Rost nosal } \\
\text { sosce in ist } \\
\text { toon }\end{array}$ & 3a & 278 & t1 & $\begin{array}{l}\text { robsered } \\
\text { side cosco }\end{array}$ & 28 & 51.9 & 3 \\
\hline Was & 163 & 646 & 6 & $\begin{array}{c}\text { Lansyaph } \\
\text { cukindo of the } \\
\text { hovse }\end{array}$ & 30 & 182 & 12 & $\begin{array}{c}\text { Sot } \\
\text { Lavducepe }\end{array}$ & 24 & stat & 6 \\
\hline bongese & 150 & 72.4 & 2 & Limblobipte & $2]$ & $17 . A$ & 12 & $\begin{array}{c}\text { Hero } \\
\text { inscheve }\end{array}$ & 12 & 222 & 9 \\
\hline $\begin{array}{l}\text { Powhi } \\
\text { pawenent }\end{array}$ & 120 & 636 & 4 & Gule & 129 & 382 & 8 & Eudaryy & 6. & $11 \mathrm{t}$ & 12 \\
\hline Roos & 64 & 39.9 & 17 & Dow & 107 & CA.4 & 5 & $\begin{array}{c}\text { Tarras } \\
\text { pros }\end{array}$ & 10 & s.s & 11 \\
\hline $\begin{array}{l}\text { Hind } \\
\text { Lirdicape }\end{array}$ & to & 212 & 14 & Whectes & $w$ & 50. & 6 & Crte & 30 & 55.6 & 2 \\
\hline Baren & 67 & 38.4 & 11 & Ficerves & 18 & nts & a & Pivring & 41. & 75.9 & 1 \\
\hline $\begin{array}{l}\text { Landurape } \\
\text { owkese } \\
\text { man gete. }\end{array}$ & 44 & nas & 13 & Wall & ni: & 410 & s & Antivg & 25 & 85.8 & 8 \\
\hline Rroory & 20 & 106 & 15 & Pansop & 128 & 200 & 1 & Courvard & 12 & 22.2 & 9 \\
\hline $\begin{array}{c}\text { Temion' } \\
\text { detis }\end{array}$ & 20 & 10.6 & 19 & dede & 50 & 345 & 10 & & & & \\
\hline Ponkes & 152 & 80.4 & 1 & Othen: & $\gamma$ & 48 & 14 & & & & \\
\hline $\begin{array}{l}\text { Mddisseal } \\
\text { entrevp }\end{array}$ & 60 & 25 & 9 & & & & & & & & \\
\hline $\begin{array}{l}\text { Rodional } \\
\text { soise }\end{array}$ & as & 360 & $x$ & & & & & & & & \\
\hline Conen & 11 & 56 & 12 & & & & & & & & \\
\hline
\end{tabular}

\subsection{The process of modification and level of satisfaction}

The modification process takes in the form of renovation done in one occasion or renovation works in stages. Based on Table 2, $80 \%$ of the renovation works for all three areas of modifications were done all at once and only $20 \%$ were conducted in stages. In relation to the level of satisfaction, Table 2 shows that the respondents were generally satisfied and happy with the renovation works done to their houses. Renovation works done in one occasion or in stages showed high a percentage of satisfaction with the side portion area having the highest percentage with $95 \%$ of the respondents satisfied, followed by the front portion area with $94 \%$ and back portion area at $81 \%$. However, $15 \%$ of the respondents who renovated the back portion were not happy and showed dissatisfaction. Modifications done in one occasion was very much more preferred compared to renovation works done in stages. But, when it comes to the level of satisfaction, most respondents 
were happy and satisfied or very satisfied with the renovation works done regardless whether the renovation was done all at once or in stages.

\subsection{Reasons for personalisation}

People modify their houses because of many reasons. They may make simple modifications or even change the entire appearance of their dwellings. Based on the survey done for this study, different parts of the house were associated with a particular reason. For the front portion of the modification, the changes done were inclined towards personal needs with the top three reasons to make the house more aesthetically beautiful, for security measures and the need for additional parking space. This was based on the ranking score of multiple responses as shown in Table 3.

Meanwhile, for the back portion of the terrace house modifications, the reasons given were more of a functional requirement and for the needs of the family. The need for bigger kitchen space was ranked number I. The existing space for kitchen was not big enough and with the land available at the backyard, the extension of the kitchen became a possibility. Modification to have a wet kitchen area was ranked number 2. This was a common extension made and the original design kitchen was thus used as a dry kitchen. Security reasons were also among the top three reasons as it provided the feeling of a safer personalised security.

For the side portion terrace house modifications, besides for personal needs, the modifications were also for aesthetic appeal. The highest ranking was to have more space for a bigger family. Having a bigger corner lot size, respondents were able to design their yards according to their own preferences. Therefore, the second reason was to make the space more pleasing with landscaping elements which also provided further privacy and personalisation.

\subsection{Conclusion and Recommendations}

Whilst a more comprehensive study on the perceived achievement of each personalisation element through the perspective of each owner could be laboriously done in further studies, some patterns has nevertheless been able to be observed. Firstly, as in the critical comments of Professor Mohamad Tajuddin Mohamad Rasdi in The Star (Rasdi, 2009), on visual privacy violations in a multi-racial country like Malaysia has been constantly dismissed in the modern developments of housing estates, especially terrace housing. The lack of mutual understanding and respect of rituals and cultural values has possibly also contributed indirectly to the immediate personalisation of the terrace house. In this specific study, it is only true representing the ethnic group of the Malays, as outlined in its limitations earlier. It is only prudent; in order to better understand the holistic Malaysian context, further studies need to be made to other communities of other races, cultures and values. 


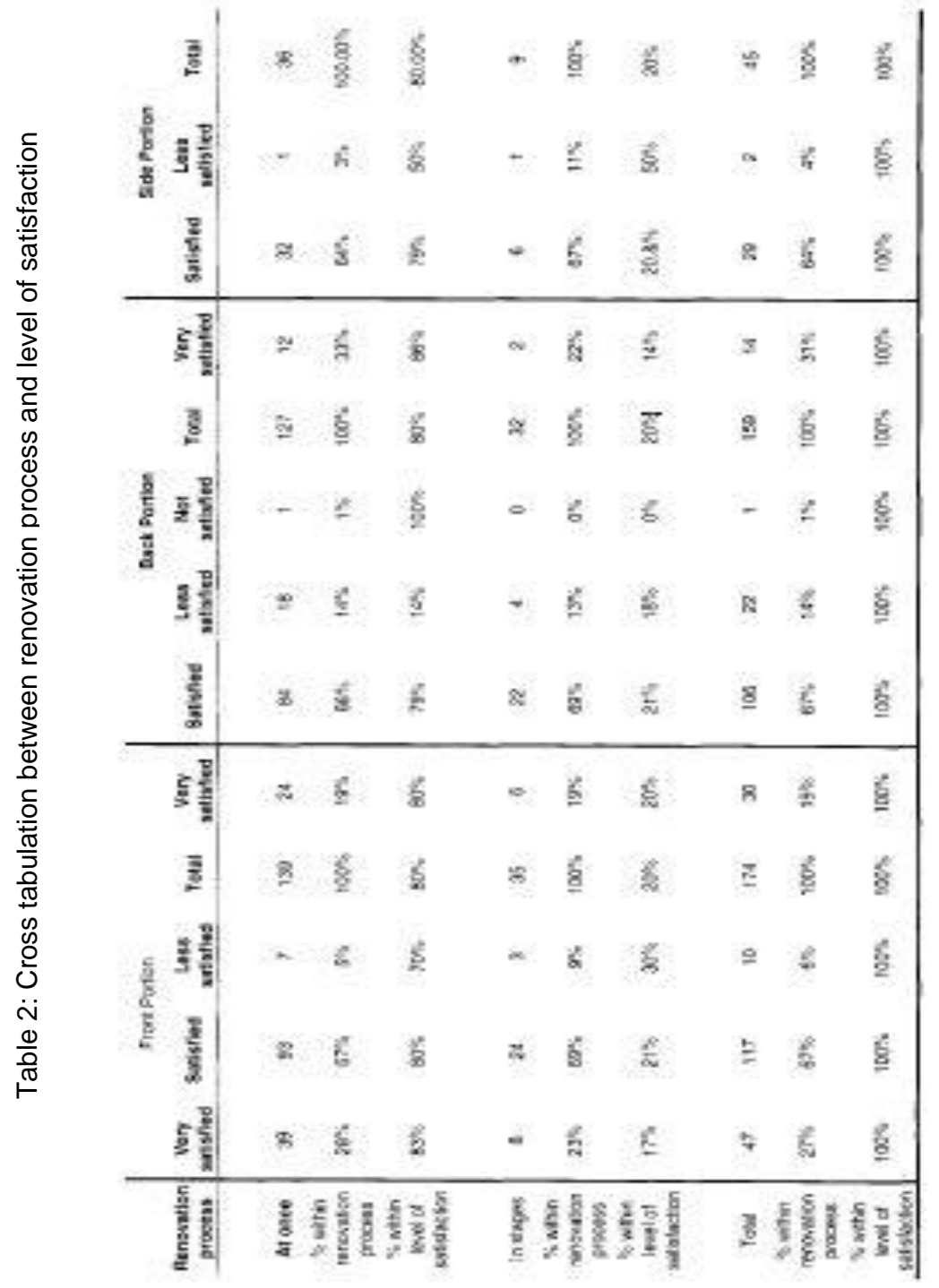


Table 3: Reasons for modifications

\begin{tabular}{|c|c|c|c|c|c|c|c|c|c|c|c|}
\hline $\begin{array}{l}\text { Front } \\
\text { pentos of } \\
\text { the newe }\end{array}$ & Conat & 5 & Narbiry & $\begin{array}{l}\text { Bock } \\
\text { porticen of } \\
\text { The hourio }\end{array}$ & Count & $\%$ & Narbang & $\begin{array}{l}\text { Secenosen } \\
\text { of the } \\
\text { nowke }\end{array}$ & Count & 3 & Rasking \\
\hline $\begin{array}{l}\text { Idarity } \\
\text { andinive }\end{array}$ & 77 & dt $B$ & 5 & 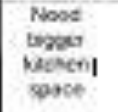 & 190 & 20.5 & 1 & 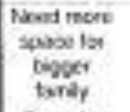 & 29 & se. & $\mathbf{1}$ \\
\hline 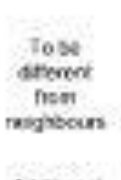 & $4 r$ & 255 & 6 & 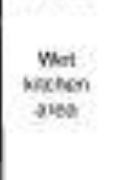 & $9 c$ & 88.4 & 2 & 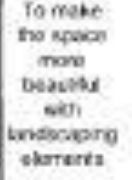 & $2 \pi$ & so.s & $z$ \\
\hline $\begin{array}{l}\text { Addtenci } \\
\text { erwacy } 8 \\
\text { potsonal } \\
\text { trueh }\end{array}$ & 72 & 30.1 & 6 & soung & ds & 462 & 3 & $\begin{array}{c}\text { Phocy and } \\
\text { perional } \\
\text { wern }\end{array}$ & 72 & 41.5 & 3 \\
\hline $\begin{array}{l}\text { Costab the } \\
\text { osginol } \\
\text { drough }\end{array}$ & 4s & 26.5 & 9 & 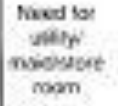 & 60 & 31 & 4. & $\begin{array}{c}\text { beribly and } \\
\text { inage }\end{array}$ & 19 & 36.8 & 4 \\
\hline $\begin{array}{l}\text { Need by } \\
\text { pasing } \\
\text { speren }\end{array}$ & E4 & 55 & 3 & $\begin{array}{l}\text { Space } \\
\text { for dying } \\
\text { dotese }\end{array}$ & $\mathbf{z}$ & $x .1$ & 5 & 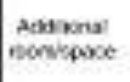 & 16 & 202 & 5 \\
\hline 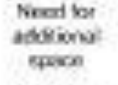 & 81 & 44 & 4 & $\begin{array}{l}\text { Felporse. } \\
\text { viritrum }\end{array}$ & 44 & 285 & 6 & Socarion & 10 & 302 & 5 \\
\hline $\begin{array}{l}\text { To neak: } \\
\text { c mowe } \\
\text { basasud }\end{array}$ & 190 & 570 & 1 & 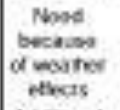 & 29 & 199 & $y$ & 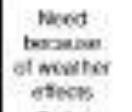 & 12 & 229 & $\boldsymbol{y}$ \\
\hline Steoulty & $\infty$ & 41.4 & 2 & $\begin{array}{l}\text { Adsitered } \\
\text { rocen id } \\
\text { frst fiect }\end{array}$ & 20 & 153 & B & $\begin{array}{l}\text { To be } \\
\text { dfhorer } \\
\text { rom aters }\end{array}$ & 1 & 1.2 & 8 \\
\hline $\begin{array}{l}\text { Nosod } \\
\text { bobarso } \\
\text { of unostar } \\
\text { efrects }\end{array}$ & $4 a$ & 26.6 & $\boldsymbol{T}$ & Desen: & 3 & 1.5 & 9 & & & & \\
\hline Conets & 5 & 27 & \& & & & & & & & & \\
\hline
\end{tabular}

Sensitive and unique, these areas of studies are solely applicable to Malaysia and its inherent multi-ethnicity of residents. Secondly, the continuous question that one may ponder and leading to a larger equation, is the very development of terrace housing in Malaysia. Its originality in its purpose and adoption, from the age of colonialism in young Malaya, to its continuing implementation in modern Malaysia, is it still fundamentally applicable? These current questions of sustainability and adoptability of culture, climate and needs in terrace developments are voiced out by many concerned architects, designers and end users alike, advocating for an alternative to terrace developments (Davis, et al., 2(06), (Yahya, et al., 2(06) and (Sabri, et al., 2(08)

This study, within its own limited context and capacity has undeniably implied that 
personalisation occurs willingly and spontaneously among new and old owners of terrace developments. Personalisation will transpire no matter how effective the architects and designers are able to design and cater to the individual's needs. The broader perspective is to digest and inquire on the patterns of personalisation, within Malaysia's terraced housing context. Are all the patterns of personalising, even for the need of a bigger kitchen, the result of improper terrace housing designs or the ultimate failure of terraced developments within the Malaysian domain?

\section{Acknowledgement}

It is with due gratitude that this study was made possible by the Fundamental Research Grant Scheme (FRGS) provided by the Malaysian Ministry of Higher Education (MOHE). Our appreciation and thanks also goes to Universiti Teknologi MARA (UiTM) for its relentless support.

\section{References}

Abdel-Kadcr, N. (1989) User's Identity Within The Neighborhood. International Journal for Housing Science and Its Applications, 13, 149-158.

Al-Kodmany, K. (1999) Residential Visual Privacy: Traditional and Modern Architecture and Urban Design. Journal of Urban Design, 4, 283.

Annison, J. E. (2000) Towards A Clearer Understanding of The Meaning of "Home". Journal of Intellectual \& Developmental Disability, 25, 251-262.

Davis,M. P., Ghazali, M.,\& Nordin, N. A. (2006). Thermal Comfort Honeycomb Housing: The Affordable Alternative to Terrace Housing. Serdang: Institute of Advanced Studies, UPM.

De Jonge, D. (1986) On The Appreciation Of Visual Diversity In Housing Environments. Journal of Housing and the Built Environment, 1,299-304.

Fernandez Esquer, M. E. (1986) Territorial Personalization of Front yards in a Mexican Public Housing Project. United States, The University of Arizona.

Gifford, R., Hine, D. W., Mullcr-Clcmrn, W., Reynolds JR., D. J., \& Shaw, K. T. (2000). Decoding Modern Architecture: A Lens Model Approach for Understanding the Aesthetic Diffrcnccs of Architects and the Laypersons. Environment and Behavior (32), 163.

Hansen, W. B., \& Altman, I. (1976). Decorating Personal Places: A Descriptive Analysis. Environment and Behavior (8), 491-504.

Harris, C. Y. P. (2005) Students' perceptions of personalization. United States, University of Houston.

Hashim, A. H., Ali, H. M. \& Samah, A. A. (2009) Urban Malays' User-Behaviour and Perspective on Privacy and 
Sazally, S.H., et.al., / Asian Journal of Environment-Behaviour Studies, ajE-Bs, 1(1), Maiden, December 2016 (p.37-48)

Spatial Organization of Housing. International Journal of Architectural Research, 3,197-208.

Hashim, A. H., Rahim, Z. A., Rashid, S. N. S. A. \& Yahaya, N. (2004) Visual Privacy And Family Intimacy: A Case Study Of Malay Inhabitants Living In Two-Store Low-Cost Terrace Housing. Environment and Planning B: Planning and Design, 33,301-318.

Heywood, F. (2005) Adaptation: Altering The House To Restore The Home. Housing Studies, 20, 531-547.

Jin, J. H. (1989) Home Environment As Symbol Of Identity. United States, University of Pennsylvania.

Lawrence, R. J. (1987) What Makes a House a Home? Environment and Behavior, 19, 154-168.

Machado, S. R. (2004) Personalization in Affordable Housing. Faculty of Architecture and Planning. Halifax, Nova Scotia, Dalhousie University.

Marcus, C. C; \& Sarkissian, W. (1986). Housing as if People Mattered: Site Design Guidelines for the Planning of Medium-Density Family Housing. USA: University California Press.

Martin-Rutherford, J. E. (2005) Personalization And Its Place In The New Urbanism. United States, University of Louisville.

MBSA (2004). Maklumat Perumahan Dalam Pcntadbiran Majlis Bandaraya Shah Alam (In Malay). Shah Alam: Jabatan Perancang Bandar, Majlis Bandaraya Shah Alam.

McCormick, J. (1993) Can houses become homes? Newsweek, 121, 71.

Mohd Jusan, M. (2007) Personalization As A Means Of Achieving Person-Environment Congruence In Malaysian Housing. Skudai. Universiti Teknologi Malaysia.

Nalkaya, S. (1980) The Personalization Of A Housing Environment: A Study Of Levittown, Pennsylvania. United States, University of Pennsylvania.

Rasdi, M. T. (2009). Positive Policies. The Star, Sunday Star Mag. Kuala Lumpur: The Star, August 16th.

Rodriguez Machado, S. (2004) Personalization In Affordable Housing. Canada, Dalhousie University (Canada).

Sabri, B., Davis, M. P., Yahya, N., \& Bajunid, A. F. I. (2008). Nong Chik Honeycomb Housing Project -Potential Buyers in RM290k-390k Price Range, UPM Random Survey in Bandar Baru UDA, Johor Baru, Universiti Putra Malaysia \& Universiti Teknologi MARA. Serdang: Universiti Putra Malaysia.

Stamps, A. E. (1999). Physical Determinants of Preferences for Residential Facades. Environment and Behavior (31), 723 .

Yahya, N., Sabri, B., Davis, M. P., \& Ghazali, M. (2006). Honeycomb Housing versus Conventional Housing... 20 Times More Potential Buyers for Honeycomb, UPM Survey at Lobby of Government Office Johor Baru. Universiti Putra Malaysia \& Arkitek M. Ghazali. Serdang: University Putra Malaysia. 